\title{
Ethno-medicinaly important herbs of Ramnagar forest division in Kumaon Region
}

\author{
Shikha Pant \\ Received: 25.10 .2012
}

Revised: 05.01.2013

Accepted: 28.02.2013

\begin{abstract}
The present study deals with Ethno-medicinally important herbs and their uses in the Ramnagar forest division. The study records 30 species of herbs belongs to 22 different families and their local herbal uses to cure different ailments by the local inhabitants. The currently accepted botanical names, family, local names, parts used and the medicinal uses of those parts are given.
\end{abstract}

Keywords: Ailments, bhabar, ethno-medicine, Kumaon, Ramnagar, traditional

\section{Introduction}

Ramnagar Forest Division is an important forest division of Western Circle of the forest of Uttarakhand which occupies an area of about 48,700 hectares and mostly occupies the Bhabar area with low Siwalik Hills in some parts.

Bhabar is a waterless area composed of bed of boulders, gravels and silt brought down by the Himalayan streams and rivers. These extremely porous deposits are fairly deep. The Siwaliks consist of tertiary coldoremates and sandstone. The average rainfall in the area is about $1300 \mathrm{~mm}$. About $80 \%$ of the rain fall is received from June to September, directly due to monsoon currents. Winter rains are scanty. Heavy dew occurs at night time from November to March. Temperature is very high from April to June. Though cool "dadu" brings some respite from heat. Frost is registered during night in December and January. The Sal forests are dominant in the area. They are present in the area with low slopes. Some deciduous species are associates with Sal forest. These deciduous riverian forests of Dalbergia sissoo and Acaia catechu on sandy and gravelly deposits along the rivers and streams. Deciduous miscellaneous forests of riverian type also occur in the area.

\section{Author's Address}

27- Moolchand enclave “Shantikunj” Majra-248171 Opp. Big bazar Dehradun, Uttarakhand.

E-Mail: pant.shikha84@rediffmail.com; sh1pasta@gmail.com.
Composed of many different species including Mallotus philippinensis, Bombax ceiba, Haldina cordifolia, Lagerstromia parviflora, Holarrhena pubescens, Cassia fistula etc. Tall grasses also occur in Bhabar area with other woody elements. Due to the richness in vegetation, the area has a great number of herbaceous species which have been used by the local inhabitants and tribes for their day to day life and in the treatment of certain ailments.Though, a good number of research work (Osmaston (1927), Duthie (1903-1929), Pant (1976-1981), Gupta (1960-1968), Jain (1956-1996), Uniyal (1997), Kalakoti and Pangtey (1988), Pandey et al. (1989-99), Joshi and Pande (19961999), Joshi (1993) and Shah (1970-1971) have contributed to the systematics and the ethnobotany of higher altitudinal regions but a little has been done for the lower altitudinal regions. The present paper is a small step to fill up that lacuna.

\section{Material and Methods}

The present study was based on a field survey (2008-2009) in Ramnagar Forest Division, to find the herbs of medicinal value. The survey was conducted among the local people, local tribes, farmers, local vaidyas and a middle aged woman's who use these plants in their day to day life. These people have a vast knowledge about the medicinal uses of plants growing around them. 
During survey the information gathered on the basis of prepared questionnaire viz., local name, mode of preparation, medicinal parts and parts used etc. Standard methods were followed for the collection of plant materials, mounting, preparation and preservation of plant species (Jain \& Rao, 1978). The preliminary identification of specimens was done with the help of manuals and floras and later confirmed after matching with the authentic specimens present in the herbaria of Northern Circle of Botanical Survey of India, Dehradun (BSD) and Forest Research Institute, Dehradun (DD). Out of these an alphabetical list including the plant name, local name, family, parts used and medicinal uses were also made (Table 1 ).

\section{Results and Discussion}

The present study records 30 herbaceous species of ethno-medicinal plants representing 22 families. In which 4 genera with 4 species belong to monocotyledonous family and 25 genera with 26 species are of dicotyledonous family. The following is the list of some important medicinal herbs found in the Ramnagar Forest Division along with their local name(s), family, parts used and their ethnomedicinal uses (Table 1).

Table 1: List of Ethno-medicinally Important Herbs and their Uses

\begin{tabular}{|c|c|c|c|c|c|}
\hline $\begin{array}{l}\text { S. } \\
\text { No }\end{array}$ & $\begin{array}{c}\text { Botanical } \\
\text { Name }\end{array}$ & $\begin{array}{l}\text { Local } \\
\text { Name }\end{array}$ & Family & $\begin{array}{l}\text { Parts } \\
\text { Used }\end{array}$ & Uses \\
\hline 1. & $\begin{array}{c}\text { Ageratum } \\
\text { conyzoides L. }\end{array}$ & $\begin{array}{l}\text { Bhubania, } \\
\text { Phulaina }\end{array}$ & Asteraceae & $\begin{array}{l}\text { Root and } \\
\text { Leaves }\end{array}$ & $\begin{array}{l}\text { Leaf paste is used for treating cut wounds to } \\
\text { check bleeding. Poultice of the leaves is good } \\
\text { for boils and juice is used as a lotion for eyes. } \\
\text { Root paste is used to set dislocated bones and } \\
\text { the powders of roots are used for cuts, sores and } \\
\text { ruptures caused by leprosy. }\end{array}$ \\
\hline 2. & $\begin{array}{l}\text { Argemone } \\
\text { mexicana L. }\end{array}$ & Pilikateli & Papaveraceae & $\begin{array}{l}\text { Root, } \\
\text { Seed, } \\
\text { Milky } \\
\text { juice and } \\
\text { Oil }\end{array}$ & $\begin{array}{l}\text { The leaves juice and seed oil is applied in skin } \\
\text { diseases and wounds healing properties. } \\
\text { The paste of root is applied on scorpion bite and } \\
\text { in severe stomachache. Root is burnt to provide } \\
\text { heat in treatment of piles. } \\
\text { Seed oils used for massage and paste of seed is } \\
\text { useful in rheumatic disorders. Yellow juice of } \\
\text { plant is used for dropsy, jaundice and cutaneous } \\
\text { affections. }\end{array}$ \\
\hline 3. & $\begin{array}{l}\text { Andrographis } \\
\text { paniculata } \\
\text { Nees }\end{array}$ & Kalmegha & Acanthaceae & $\begin{array}{l}\text { Whole } \\
\text { Plant }\end{array}$ & $\begin{array}{l}\text { It is considered to be useful for children and not } \\
\text { so much for older persons. It is useful for all } \\
\text { type of fevers, malaria, mouth ulcers and } \\
\text { venomous snake bites and also useful in } \\
\text { common cold, urinary infections, dysentery and } \\
\text { infectious hepatitis. }\end{array}$ \\
\hline 4. & $\begin{array}{l}\text { Aerva lanata } \\
\text { (L.) Juss. ex } \\
\text { Schult. }\end{array}$ & Chaya & Amaranthaceae & $\begin{array}{c}\text { Leaves } \\
\text { and Root }\end{array}$ & $\begin{array}{l}\text { Roots are used in headache and decoction of the } \\
\text { root is Given as tonic to pregnant women. } \\
\text { Leaf juice is used as effective remedy to expel } \\
\text { the kidney stones. It is also useful for any } \\
\text { irritation and for skin diseases. }\end{array}$ \\
\hline 5. & $\begin{array}{c}\text { Blumea } \\
\text { fistulosa } \\
\text { (Roxb) Kurz. }\end{array}$ & Kukraida & Asteraceae & Leaves & Leaves used for body ache. \\
\hline 6. & $\begin{array}{c}\text { Baliospermu } \\
\text { m montanum } \\
\text { (Willd.)Muell } \\
\text {--Arg. }\end{array}$ & Danti & Euphorbiaceae & Seeds & $\begin{array}{l}\begin{array}{l}\text { Small quantity of seeds taken orally in } \\
\text { constipation. }\end{array} \\
\end{array}$ \\
\hline 7. & Boerhavia & Punarnava & Nyctaginaceae & Whole & Juice of fresh roots is used as eye drops. \\
\hline
\end{tabular}




\begin{tabular}{|c|c|c|c|c|c|}
\hline & diffusa $\mathrm{L}$. & & & Plant & $\begin{array}{l}\text { Root juice is administered orally in asthma and } \\
\text { urinal disorder. Watery extract of the root is } \\
\text { given orally in jaundice. } \\
\text { Leaves paste is useful in skin diseases like } \\
\text { scabies. }\end{array}$ \\
\hline 8. & $\begin{array}{l}\text { Basella alba } \\
\quad \text { L. }\end{array}$ & Poi & Basellaceae & $\begin{array}{l}\text { Root and } \\
\text { Leaves }\end{array}$ & $\begin{array}{l}\text { Poultice of leaves used to reduce local swelling. } \\
\text { Leaf juice thoroughly rubbed and mixed with } \\
\text { butter is a soothing and cooling application for } \\
\text { burns and scalds. } \\
\text { Cooked roots are used for diarrhea. } \\
\text { Cooked leaves and stem are used as antidote to } \\
\text { poison. }\end{array}$ \\
\hline 9. & $\begin{array}{c}\text { Cleome } \\
\text { viscosa } \mathrm{L} .\end{array}$ & Jakhya & Capparaceae & Leaves & Leaves juice used in earache. \\
\hline 10. & $\begin{array}{l}\text { Cannabis } \\
\text { sativa L. }\end{array}$ & Bhang & Cannabaceae & $\begin{array}{l}\text { Leaf, } \\
\text { Seeds, } \\
\text { Flower } \\
\text { and Fruit }\end{array}$ & $\begin{array}{l}\text { Paste of leaf is applied on wisdom tooth. } \\
\text { Paste of seeds is used a remedy for knots in } \\
\text { joints. } \\
\text { The Plant is useful in asthma, burns, coughs, } \\
\text { diarrhea, dysentery, fever, gonorrhea and for } \\
\text { rheumatism. }\end{array}$ \\
\hline 11. & $\begin{array}{l}\text { Curcuma } \\
\text { longa L. }\end{array}$ & $\begin{array}{l}\text { Jungli } \\
\text { haldi }\end{array}$ & Zingiberaceae & $\begin{array}{l}\text { Tubers } \\
\text { and } \\
\text { Rhizome }\end{array}$ & $\begin{array}{l}\text { Due to strong antiseptic properties it is useful } \\
\text { for all kinds of poisonous affections. } \\
\text { Rhizome juice along with honey is used for } \\
\text { anemia. } \\
\text { Fresh tuber juice with salt is used for intestinal } \\
\text { worms. } \\
\text { The paste of herb mixed with salt and lime juice } \\
\text { used to cure swellings and sprain. }\end{array}$ \\
\hline 12. & $\begin{array}{l}\text { Centella } \\
\text { asiatica } \mathrm{L} .\end{array}$ & Brahmi & Apiaceae & $\begin{array}{l}\text { Whole } \\
\text { Plant }\end{array}$ & $\begin{array}{l}\text { The plant a valued medicine for treatment of } \\
\text { leprosy and skin diseases and also to improve } \\
\text { memory. } \\
\text { Poultice of plant is used for rheumatism. } \\
\text { A decoction of young shoots is given for } \\
\text { hemorrhoids. } \\
\text { The leaves are useful in abdominal disorders } \\
\text { due to dysentery in children. }\end{array}$ \\
\hline 13. & $\begin{array}{l}\text { Fagopyrum } \\
\text { esculentum } \\
\text { Moench }\end{array}$ & Ugal & Polygonaceae & $\begin{array}{l}\text { Bark and } \\
\text { Seeds }\end{array}$ & $\begin{array}{l}\text { Bark and seeds are used to cure diarrhea and } \\
\text { extreme dehydration. }\end{array}$ \\
\hline 14. & $\begin{array}{c}\text { Gloriosa } \\
\text { superba L. }\end{array}$ & Langhi & Liliaceae & $\begin{array}{l}\text { Root and } \\
\text { Rhizome }\end{array}$ & $\begin{array}{l}\text { Paste of root is applied externally on joins for } \\
\text { muscular pain. } \\
\text { Rhizome is useful for skin diseases and leprosy. }\end{array}$ \\
\hline 15. & $\begin{array}{c}\text { Ipomoea } \\
\text { quamoclit L. }\end{array}$ & $\begin{array}{c}\text { Lal } \\
\text { Bharad }\end{array}$ & Convolvulaceae & $\begin{array}{l}\text { Whole } \\
\text { Plant }\end{array}$ & $\begin{array}{l}\text { Plant decoction is used in piles and as an } \\
\text { antidote for snake bite. }\end{array}$ \\
\hline 16. & $\begin{array}{l}\text { Ipomoea nil } \\
\text { (L.) Roth }\end{array}$ & Bharad & Convolvulaceae & Seeds & $\begin{array}{l}\text { Seeds are useful in constipation, skin diseases, } \\
\text { and scabies and for leucoderma. }\end{array}$ \\
\hline 17. & $\begin{array}{c}\text { Impatiens } \\
\text { balasamina . }\end{array}$ & $\begin{array}{l}\text { Gulmendh } \\
\text { i }\end{array}$ & Balsaminaceae & Seeds & $\begin{array}{l}\text { Paste of seed is applied externally in skin } \\
\text { diseases. }\end{array}$ \\
\hline 18. & $\begin{array}{c}\text { Mentha } \\
\text { arvensis L. }\end{array}$ & Pudina & Lamiaceae & Leaves & $\begin{array}{l}\text { Fresh leaves taken during dysentery; leaf paste } \\
\text { used to massage in body aches. }\end{array}$ \\
\hline 19. & $\begin{array}{l}\text { Oxalis } \\
\text { corniculata } \\
\text { L. }\end{array}$ & $\begin{array}{l}\text { Khatta- } \\
\text { Meetha }\end{array}$ & Oxalidaceae & $\begin{array}{l}\text { Whole } \\
\text { Plant }\end{array}$ & $\begin{array}{l}\text { Juice of herb is used as eye drops on cataract. } \\
\text { Paste of shoots along with black pepper is } \\
\text { applied to boil, wound and weeping eczema. } \\
\text { Leaves and roots are used to treat dysentery }\end{array}$ \\
\hline
\end{tabular}




\begin{tabular}{|c|c|c|c|c|c|}
\hline 20. & $\begin{array}{l}\text { Phyllanthus } \\
\text { niruri L. }\end{array}$ & $\begin{array}{l}\text { Bhumiya } \\
\text { amla }\end{array}$ & Euphorbiaceae & $\begin{array}{l}\text { Whole } \\
\text { Plant }\end{array}$ & $\begin{array}{l}\text { Infusion of the leaf taken for jaundice, } \\
\text { gonorrhea and urinary tract infection. Powdered } \\
\text { leaf and root are drunk for colic, cough and } \\
\text { indigestion. It is also used to treat gout, kidney } \\
\text { disorders and impotence. }\end{array}$ \\
\hline 21. & $\begin{array}{l}\text { Piper longum } \\
\text { L. }\end{array}$ & Pipli & Piperaceae & $\begin{array}{l}\text { Whole } \\
\text { Plant }\end{array}$ & $\begin{array}{l}\text { The plant is commonly used to treat } \\
\text { stomachache, bronchitis, cough, tumors, } \\
\text { insomnia, epilepsy, gonorrhea, diarrhea and } \\
\text { cholera. } \\
\text { Paste of seed is applied externally to sooth and } \\
\text { relieves muscular pain. }\end{array}$ \\
\hline 22. & $\begin{array}{l}\text { Physalis } \\
\text { minima L. }\end{array}$ & $\begin{array}{l}\text { Bandhapa } \\
\text { riya }\end{array}$ & Solanaceae & $\begin{array}{l}\text { Whole } \\
\text { Plant }\end{array}$ & $\begin{array}{l}\text { Poultice of plant is used to treat headache, } \\
\text { gastralgia and intestinal pain; also used to treat } \\
\text { fever. Decoction of the plant is taken to ensure } \\
\text { normal urination. } \\
\text { A paste of leaves and stems is used to treat } \\
\text { dizziness and juice of leaves, mixed with } \\
\text { mustard oil and water used for earache. }\end{array}$ \\
\hline 23. & $\begin{array}{l}\text { Rumex } \\
\text { hastatus D. } \\
\text { Don }\end{array}$ & Chilmora & Polygonaceae & $\begin{array}{l}\text { Whole } \\
\text { Plant }\end{array}$ & $\begin{array}{l}\text { Root decoction is used for rheumatism. } \\
\text { Leave juice is given in abdominal colic. }\end{array}$ \\
\hline 24. & $\begin{array}{l}\text { Rungia } \\
\text { repens Nees }\end{array}$ & Kharmar & Acanthaceae & $\begin{array}{l}\text { Whole } \\
\text { Plant }\end{array}$ & $\begin{array}{l}\text { Dried herb is used in the treatment of cough and } \\
\text { fever. } \\
\text { Fresh, bruised leaves are mixed with castor oil } \\
\text { used for scaly fungous infection. }\end{array}$ \\
\hline 25. & $\begin{array}{l}\text { Ranunculus } \\
\text { sceleratus L. }\end{array}$ & Jaldhaniya & Ranunculaceae & Roots & $\begin{array}{l}\text { Roots are useful in dysentery, diarrhea, stomach } \\
\text { disorder, fever, vomiting, inter inflammatory } \\
\text { condition and also useful in skin disorder. }\end{array}$ \\
\hline 26. & $\begin{array}{c}\text { Senecio } \\
\text { nudicaulis } \\
\text { Buch.-Ham } \\
\text { ex D. Don }\end{array}$ & Ratpatia & Asteraceae & $\begin{array}{l}\text { Whole } \\
\text { Plant }\end{array}$ & $\begin{array}{l}\text { Juice of leaves is dropped in eyes in } \\
\text { conjunctivitis. } \\
\text { Paste of herb and leaves is applied on wounds. }\end{array}$ \\
\hline 27. & $\begin{array}{l}\text { Solanum } \\
\text { nigrum L. }\end{array}$ & Makoi & Solanaceae & $\begin{array}{l}\text { Whole } \\
\text { Plant }\end{array}$ & $\begin{array}{l}\text { Juice of whole plant is given for fever. } \\
\text { Paste of leaves with black pepper is applied } \\
\text { over boils and pimples. }\end{array}$ \\
\hline 28. & $\begin{array}{l}\text { Sesamum } \\
\text { orientale L. }\end{array}$ & Til & Pedaliaceae & Seeds & $\begin{array}{l}\text { Small quantity of seed oil is taken orally for } \\
\text { dysentery. }\end{array}$ \\
\hline 29. & Zea mays L. & Bhutta & Poaceae & Fruits & Decoction of corn is used to treat kidney stones. \\
\hline 30. & $\begin{array}{l}\text { Zingiber } \\
\text { officinale } \\
\text { Roscoe }\end{array}$ & Adrak & Zingiberaceae & Rhizome & $\begin{array}{l}\text { Rhizome used in throat pain, cold, cough and } \\
\text { bronchitis. }\end{array}$ \\
\hline
\end{tabular}

Various parts of these species such as whole plant (12), roots (6), seeds (7), flower(1), fruit(2), rhizome(3), tuber(1), bark(1) and oil (1) were used to cure different ailments (Fig. 1). Most of the plant species are reported to be quite effective remedies for different diseases such as diarrhea, diabetes, jaundice, backache, stomachache, toothache, ulcers, cold, skin related problem and feminine problems. The present study has been designed to explore the ethno- medicinal significance of the herbaceous flora of this region. However it's pity to note that owing to rampant deforestation, cultivation, burning of jungle, over-exploitation, fire wood collection, grazing and browsing, lopping and other human socio-economic development activities, the rich flora including the wealth of medicinal plant of this region are depleting very fast day by day.Hence, there is a need of conservation and protection of these plants. 
Fig. 1: Plant partwise ethno-medicinal uses

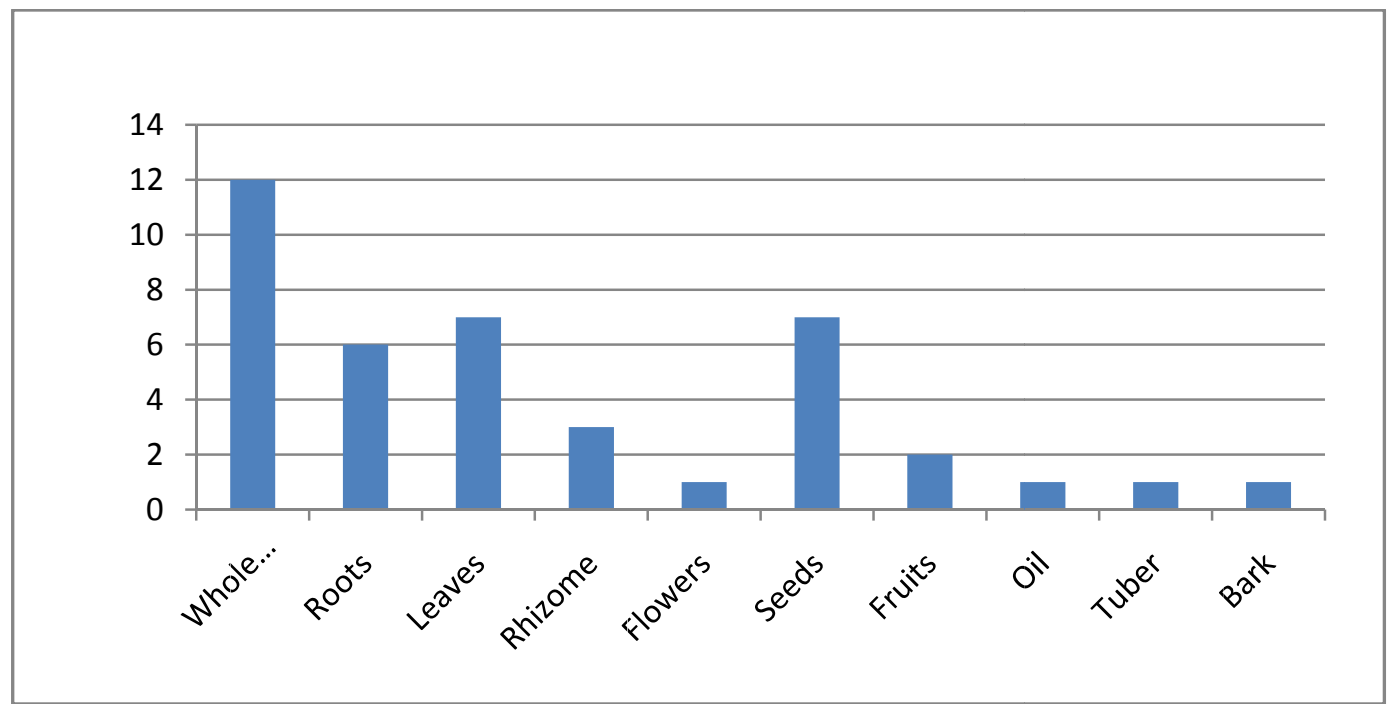

\section{References}

Duthie, J. F. 1903-1929 Flora of Upper Gangetic Plain and of the Adjacent Siwalik and Sub-Himalayan Tracts. 3 Vol., Calcutta.

Gupta, R.K. 1960 Some useful and medicinal plants of Nainital district in the Kumaon Himalaya. Indian For. 57: 309 - 324.

Gupta, R. K. 1960. Some useful and medicinal plants of Nainital in Kumaon Himalaya. J. Bomb. Nat. Hist.

Soc. 68 (3): 791- 803.

Gupta, R. 1962. Medicinal plants of West Himalaya. J. Agri. Trop. Bot. App. 9: 1 - 54.

Gupta, R. K. 1968 Flora Nainitalensis, Navayag Publishers., New Delhi.

Jain, S. K. and Rao, R. R. 1977 A Handbook of Field and Herbarium Methods, Today and Tomorrow, New Delhi

Jain, S. K. 1987 A Manual of Ethnobotany, Scientific Publishers, Jodhpur.

Jain, S. K. 1995 A Manual of Ethnobotany $2^{\text {nd }}$ ed., Scientific Publishers, Jodhpur.

Joshi, Pramila. 1993 Ethnobotany of the Tribal Communities of the Kumaon Himalayas. Ph. D. Thesis, submitted to Kumaon University, Nainital.

Kalakoti, B. S. and Pangety, Y.P.S. 1988 Ethnomedicine of Bhotiya tribe of Kumaon Himalaya, Uttarakhand. Bull. Med. Ethno. Res. 9: 11-20.
Osmaston, A. E. 1927 A Forest Flora for Kumaon. Govt. Press, Allahabad.

Pandey, G., Joshi, G. C., Pandey, N. K. and Pandey, G. 1994 Ethnobotanical studies on the Medicinal Flora of

Tarikhet block (Kumaon Himalaya) district Almora. U. P. part-II. Aryavaidyan 8(1): 40 - 46.

Pande, P. C., Joshi, G. C. and Kandpal, M. M. 1989 Ethnobotany of Kumaon Himalaya in Himalayan Environment. Resource and development (ed. N.K. Shah, S. D. Bhatt and R. K. Pande) Shree Almora Book Dept., Almora.

Pant, P. C. 1976. Plants of Corbett National Park . Uttar Pradesh. J. Bom. Nat. Hist. Soc. 73(21): 187-295.

Shah, N.C. and Joshi, M.C. 1971 An Ethno botanical study of the Kumaon region of India. Econ. Bot. 25: 414 - 422.

Shah, N.C. and Jain, S.K. 1980. Ethnomedicobotany of Kumaon Himalaya, India. Social Pharmacal 2: 359 - 380.

Uniyal, M. R. 1997 Medicinal Plants and Minerals of Uttarakhand Himalaya (in Hindi). Vaidhyanath Ayurved Sodh Sansthan, Patna.

Watson W. 1882 Plants of Kumaon, In Atkinson's Gazetter of N. W. P. and Oudh. 11, 299. 